\title{
INDEPENDENT LIVING CENTRES: AN INNOVATION WITH MENTAL HEALTH IMPLICATIONS?
}

\author{
PEGGY HUTCHISON \\ Brock University \\ and \\ ALISON PEDLAR \\ University of Waterloo
}

\begin{abstract}
The findings of a national study of Independent Living Centres (ILCs) in Canada suggest that the ILCs are a potentially powerful innovation for the consumer/survivor movement. Independent Living Centres are non-profit, cross-disability, consumer-driven, community-based centres which promote both individual empowerment and community change. The IL and mental health reform paradigms share in the development of empowerment theory, acknowledge the importance of consumer driven organizations, and utilize a socio-political analysis of disability which goes beyond the person and recognizes the environment as problematic. Accordingly, the reform paradigm seeks innovative services which are separate from the traditional mental health system. Before this can fully become a reality, mental health professionals need to increase their knowledge of the IL philosophy and ILC practice. Similarly, ILCs need to increase their knowledge of consumer/survivor empowerment and recovery and carefully assess any barriers that exist in terms of consumers/survivors accessing the ILCs. Collaboration between the IIL movement and mental health will increase the likelihood of ILCs becoming a stronger resource for consumers/survivors.
\end{abstract}

\section{INTRODUCTION}

A recent national study of the impact of Independent Living Centres (ILCs) in Canada has pointed to the benefits of the independent living approach in supporting all disability groups, including psychiatric consumers/survivors. It is clear, though, that consumers/survivors are among the most underrepresented people accessing the ILCs. In this article, we address several questions: (a) What are ILCs, (b) what are some of the impacts of ILCs highlighted in the national study, and (c) what are some of the implications for mental health reform (for example, how might the II.Cs and the mental health field learn from one another, and where could stronger links be made to encourage both mental health support services and II.Cs to maximize each other's resources)?

Thank you to Peter Dunn and John Lord, co-researehers on this project, and to Pat Sisco, Chairperson of the board of the Canadian Association of Independent Living Centres, a partner in this project. This research was supported by a grant from the Social Sciencer and Humanities Research Council. 


\section{WHAT ARE INDEPENDENT LIVING CENTRES?}

There is now widespread interest in developing social policies and practices that are grounded in principles of independent living (Carling, 1995; Lord \& Hutchison, 1996; Schwart, 1992). The Independent Living (IL) paradigm reflects a shift in thinking away from traditional, professionally dominated services and towards ensuring that people with disabilities have more control over their lives through self-help, self-determination, and empowerment (Budde, Feighny, White, Altus, \& Snyder, 1993; Council of Canadians with Disabilities, 1995; Rappaport, Reischl, \& Zimmerman, 1992).

Independent Living Centres (ILCs), which first emerged in Canada in the 1980s, are now a major force in the promotion of the IL concept (Lord. McGeown, Taylor, \& Young, 1992). Nationally, the Canadian Association of Independent Living Centres (CAILC) and its local affiliates promote both individual empowerment and community change. The guiding principles of the community-based and consumer-driven centres include: (a) espousing an empowerment philosophy which incorporates consumer control/self-direction over decision-making; (b) offering cross-disability support; (c) providing options/choice, flexibility, and freedom; and (d) promoting inclusion and full participation (Carpenter, 1993; Dunn, 1998; Valentine, 1994; Woodill, 1992). Core programs and functions of ILCs enable local centres to offer information and referral, individual advocacy and consultation, peer support, and research and development (Canadian Association of Independent Living Centres, 1991; Krogh \& Petric, 1994).

Of the 23 centres currently existing across Canada, 10 are in Ontario, 4 are in British Columbia, 3 are in Quebec and New Brunswick (French centres), 2 are in Saskatchewan, and Alberta, Manitoba, Nova Scotia, and Newfoundland each have 1. The centres receive a significant portion of their operating dollars from Human Resources Development Canada (HRDC) and are required by CAll.C to match these federal dollars. Examples of other sources of funding are United Way, provincial ministries, fundraising, and special projects, where a grant is received to provide a specific project (e.g. on employment or literacy). Most centres operate on a regular weekday, 9-to-5 schedule, with the exception of board and committee meetings and some social activities or peer support which might happen any time. CAILC guidelines require that a minimum of $51 \%$ of the board of each centre be comprised of individuals with disabilities. Some centres, however, require higher percentages. Size of boards varies from 8 to 15 members, and usually consists of a chair, vice-chair, and secretary/treasurer. Each centre determines its own specific structure, including which committees it will have and how the committees will operate. Most staff hired by the II.Cs and CAILC are individuals with disabilities (M. Horne, personal communication, September 27, 1999).

The IlC's promotion of a cross-disability focus includes people with physical disabilities, developmental disabilities, and sensory impairments, as well as individuals who have been involved with the mental health system. The rationale for a cross-disability focus of the ILCs, which is not dissimilar to other consumerdriven disability organizations (e.g. Council of Camadians with Disabilities), is grounded in a strong socio-political perspective which sees disability as being socially constructed (Pardo, 1996: Racino \& Heumann, 1992). Also apparent are 
persistent barriers to independent living. ranging from inaccessible buildings and inadequate wages to poverty-level social assistance (Jongbloed \& Crichton, 1990; Oliver, 1996; Zarb, 1992). The IL approach emphasizes that the problem of "disability" lies in the environment-in segregation, discrimination, and dependency on professionals (Enns, 1986; Federal Task Force On Disability Issues, 1996). The Independent Living Centres (ILCs) have been identified as a significant vehicle for responding to the socio-political context of the IL movement.

\section{THE IMPACT STUDY OF ILCS}

\section{Research Questions}

There is a growing body of literature about ILCs (Nosek, Fuhrer, \& Howland, 1992), but little research has been done on the actual impact of ILCs, particularly in the 90 's in Canada. The current study began by asking questions about the impact of the ILCs: (a) Are ILCs perceived as being helpful in overcoming the myriad of community obstacles experienced by people with disabilities; (b) how effective are ILCs as mediating structures between the IL. paradigm and the beliefs, values, and expectations of community; and (c) how do the specific programmes and services offered by ILCs contribute to their impact?

\section{Method}

A two-year study was designed to respond to these questions and to examine the impact of ILCs in Canada on the lives of people with disabilities and on the community. Three II sites were selected based on the following criteria: (a) the Centre was long-standing (c.g., over five years) and well established, (b) the Centre had a relatively strong funding base, and (c) the Centre had key core IL components in place (Hutchison et al., 1996). Qualitative individual and focusgroup interviews were carried out in Year 1 to understand the impact of ILCs on people with disabilities who used the Centres. Eighteen people, five of whom were consumers/survivors, were interviewed individually. As well, 18 focus-group interviews were held involving 70 people. In Year 2, using a quantitative survey, the study investigated the impact of ILCs on their "communities of interest" (111 of 211 surveys returned, giving a response rate of $52.6 \%$ ). The term communities of interest was used to identify specific agencies and groups that were connected to the IlCs. These included formal organizations in the community (e,g., agencies such as the Canadian Mental Health Association, government departments, hospitals, businesses, schools, unions, and funders) (53\%), informal groups in the community (e.g., self-help groups, parent support groups, community clubs, neighbourhood associations, churches) $(32.4 \%)$, and family/friends (e.g.. family members and friends of people with disabilities who use the ILCs) $(14.6 \%)$.

\section{FINDINGS}

Based on the analysis of both the qualitative and quantitative data, we include here four major themes that help explain the impact of ILCs in Canada: empowerment, internalizing the IL philosophy, fostering community change, and 
incorporating a cross-disability mandate (Hutchison, et. al., 1996; Hutchison, Pedlar, Dunn, Lord, \& Arai, in press).

\section{Empowerment}

Findings of the study indicate that IICs treat people with disabilities as valued citizens and fully contributing members of the community. Study participants report that this is significantly different from the sort of treatment which people experience elsewhere in the community, where they are seen as clients and disabled persons. People talk about the dignity that comes from being cared for and listened to, being treated with respect and fairness, feeling connected to other members of the same movement, being able to count on the ILC for support while trying to achieve more independence, and having the chance to acquire new skills. As one person explains:

1 guess what I find is that they don't do things for you, they do things with you and they guide you. You don't think that they are just another mental health worker, they do it with you, Maybe it is a good road to take .... And they have a good name, they treat us like we are independent. We work on things together.

Another person illustrates the significance of the IICs in his life:

My first contact was to get a new place to do volunteer work. I was looking for a job and because I was mentally ill I couldn't get a job. I first came in 1991 and I would sort of drop in to the ILC. I would be really lonely on weekends ... I come here to get positive support from the people because I'm mentally ill. It's a nurturing place for me. They take the time ... I smoke and have coffee; it's a good place to be. I volunteer one day a week .... We're here to run our lives as well as trying to help the center run itself, and that's what makes the office run smooth. It takes up our time, and it's a joy and a fulfiliment. At the end of the day we feel good about accomplishing something. The staff here appreciates us coming in and helping out; it makes it easier for them.

Coupled with the qualitative data from Year 1 of the study, the findings from the Year 2 quantitative survey point to the broader impact of the ILCs in relation to the communities of interest. Survey responses to questions dealing with empowerment were very positive. Using a 5-point Likert Scale (1-not at all, 2-a little, 3somewhat, 4-a lot, 5-totally), we asked about the impact of ILCs on people's sense of self-esteem and self-confidence $(M=3.739, S D=.837)$, whether the ILCs helped in gaining knowledge and awareness $(M=3.737, S D=.732)$, in gaining control over their lives $(M=3.71, S D=788)$, in strengthening social networks $(M=3.65$, $S D=816)$, in contributing to the community $(M=3.62, S D=.85)$, and in building new skills $(M=3,5, S D=.91)$.

\section{Internalizing the IL Philosophy}

Participation with ILCs leads to a clearer understanding of the IL philosophy by people with disabilities. Many people believe that the ILCs are an important tool for furthering the II. movement. Strong leadership (e.g., board of directors comprising primarily people with disabilities, hiring staff who have disabilities), participation in the "individual empowerment skills development" programs, and 


\section{INDEPENDENT LIVING CENTRES}

linking action to philosophy (e.g., having input into the decision-making process) all make a difference, as is evidenced in the following comment:

In other areas, they talk over you, they make decisions for you, then some people go back into their shell. The II.C never does that; they always give you the feeling that you are in control. They give you the feeling you can do it. They work with you and then you can do it. It shocks people that we can come out and say what we want. For psychiatry people they want to take care of you, and when they talk to the ILC they are shocked because we can do it, but the psychiatry people never give us a chance.

People's expressions of the value of the linking of the II philosophy to action are very consistent with the experience below:

I was looking for a job at the time. She helped me put together my résumé. What she really did that I liked was that she didn't tell me how to put my résumé together. She supported me and didn't control it. My résumé was really long and at the end $I$ found out she didn't think it should be that way and I really liked that. She helped me with the setup of it so it didn't look too crowded. She didn't try and change my résume, because of the whole IL philosophy.

The Year 2 survey asked the community of interest to indicate on a 5-point Likert Scale the extent to which the following components contribute to the positive impact of the ILCs on their communities: the IIC's philosophy, the ILC's leadership, and the II.C's core programs. All of these aspects appear to have relevance. The philosophy of the ILCS is clearly seen to contribute positively $(M=3.88, S D=875)$, with leadership also making a notable impact $(M=3.655$, $S D=925$ ). The survey shows that the community is less familiar with the ILC's specific core programmes (e.g., advocacy/consultation, peer support) $(M=3.545$, $S D=964)$. However, the survey results also indicate the belief that ILCs promote the independent living movement, including a philosophy of independence and selfdetermination, to a high degree $(M=4, S D=.791)$.

\section{Fostering Community Change}

The ILCs are aware of the community's attitudes and treatment of people with disabilities and consequently work towards community change. The II framework emphasizes that the problem lies in the environment (e.g., inaccessible community resources, poverty). The four major strategies employed by the ILCs to foster community change are: (a) developing partnerships, (b) playing a watch-dog role, (c) ensuring service development when needed, and (d) providing community education. People had the following observations about the relevance of these activities:

They work in a lot of partnerships with a lot of community agencies. They do have a lot of community support and they are in communication with a lot of groups. Probably on a very general basis they keep an eye on other agencies.

It is a joint effort with several community organizations .... I think that the II.C was the most instrumental in getting it going. It's ... community networking ...

In Year 2, using a 5-point Likert Scale, people were asked to rate possible explanations for perceived weaknesses of the ILCs in terms of addressing their community-change goals. Mostly clearly, lack of funding was seen as problematic $(M=3.29, S D=1.177)$. Related to funding issues, for example, a limited range of 
programs sometimes made it difficult to accomplish goals $(M=2.644, S D=1.141)$. Facilitating partnerships, educating community groups, monitoring the community's sensitivity to disability issues, and helping develop new services were all given as examples of valuable contributions to community change that needed to be continued and expanded. This quote from Year 1 illustrates some of these findings:

The ILC helps with things in the community like doing workshops and showcases. The IL.C invites service providers to come in. One of the things that has come up in the last year or so have been requests for some of the staff to go into the businesses for sensitivity training. 1 guess that since this request is coming in now it is saying that they want to be aware. With the newsletter information is going out.

\section{Incorporating a Cross-Disability Mandate}

The results indicate mixed feeling towards the cross-disability mandate. On one hand, people report that contact with the ILC leads them to appreciate what it is like to live with a disability different from their own, and enables them to see the common issues which are shared by all people with disabilities.

With all these people coming together to speak with one voice, 1 find that the
information is better. Like the newsletter, when you get information about
transportation that includes all of us. When you speak with all the handicapped
you have more clout.

On the other hand, consumers/survivors are a small minority of the users of the ILCs, and some are concerned that the ILCs don't know enough about mental health issues and resources. Perhaps this is because, historically. ILCs have been known primarily as a resource for individuals with physical disabilities.

I did take some information at one time for the community health nurse course. We were doing a project on communication. It didn't really help me; it didn't have any concrete information. They found me a few things but it didn't help me. We got a good mark but we got the information at other places. They don't really have a lot of information on psychiatric disabilities. They are more geared to physical disabilities.

Even though the Centre has a cross-disability focus, the sponsoring group has an image related to physical disabilities, so they assume that the ILC does also and doesn't know that it applies to other disabilities ... I think they have to advertise more.

Overall, about half of the people interviewed in Year 1 of the study had mobility or other physical disabilities. In general, it is clear that physical disabilities dominated at all three II.Cs, and that people with other types of disabilities were concerned with the opportunities available to them through an ILC.

The Year 2 survey results affirm the challenge that the ILCs seem to have in meeting their cross-disability mandate. In addition to assessing the impact of the four core programmes, participants were asked several other questions about more general impact. Participants indicated that they felt that ILCs promote the independent living movement to a high degree $(M=4, S D=.791)$ and that the ILCs have been very responsive to the participants ${ }^{+}$requests $(M=3.988, S D=.861)$, but the ability of the ILCs to meet their cross-disability mandate received the lowest rating $(M=3.386, S D=, 94)$. 


\section{IMPLICATIONS OF ILC IMPACT STUDY FINDINGS FOR MENTAL HEALTH}

The implications of these findings for mental health reform stem from the issues that are common to the $\mathrm{IL}$ and consumer/survivor movements. In reviewing our findings and recent mental health literature, we have found that both emphasize the importance of considering the complexity of multiple levels of understanding. More comprehensive than traditional models, this ecological way of viewing innovation suggests the need to discuss the intersection of theory, practice, and policy.

\section{Theory}

Our analysis is consistent with "theory in the making," which suggests that theories are always developing and open to new possibilities (Hooks, 1984). The IL and mental health reform paradigms reflect three parallel theories. First, they are both based on empowerment theory. Current best practices in mental health emphasize empowerment, community integration, choice and control in relationships with professionals, and access to valued resources (Carling, 1995; Nelson, Lord, \& Ochocka, in press; Trainor, Pomeroy, \& Pape, 1993). The IL paradigm emphasizes empowerment through self-help, self-determination, inclusion, and full participation (DeJong. 1993).

A second common theory is grounded in the realization that consumer-driven organizations are necessary for empowerment and the evolution of communitysupport services. This theory reflects the paradigm shift that is occurring in the disability field (DeJong, 1979; Oliver, 1996). In recent years in mental health there have been a growing number of mutual aid/self-help groups of consumers/ survivors (Lavoie \& Stewart, 1995). These consumer initiatives often reflect elements of the II philosophy, particularly the focus on peer support. An increasing number of ILCs are genuinely consumer-driven organizations. Beyond their peer support function, ILCs also emphasize information and referral, individual advocacy and consultation, and research and development (Canadian Association of Independent Living Centres, 1991). Overall, in mental health and other fields of disability, consumer-controlled organizations remain in the minority.

A third common theory which informs practice is the socio-political analysis of disability which recognizes that the problem lies within the environment, not just within the person (Oliver, 1996; Zimmerman, 1995). Mental health reform which embraces this theory no longer blames the person, but instead provides support for individual empowerment, and works to create systemic change (Nelson et al., in press). Similarly, the IL philosophy does not differentiate according to type or degree of disability. However, ILCs focus more on individual advocacy than they do on systemic advocacy. ILCs tend to leave the latter role to other disability organizations such as the Council of Canadians with Disabilities.

\section{Practice}

As noted, the findings of this research indicate that, at the ILCs, people are treated differently than they are in other places. In comparison to the rehabilitation 
agencies and traditional mental health services that have comprised the majority of consumers/survivors' experiences, ILCs look and feel very different. There appear to be at least three factors which explain what it is about the ILCs that makes it possible for them to treat people with dignity, respect, and fairness and as contributors to the IIC and the community: (a) the II. philosophy underlies all activity and provides many consumers with a framework for changing their lives; (b) the ILC's focus on a wholistic process encourages individuals to utilize information, peers, and other support to access the resources that they need within the community: and (c) the ILCs provide a diverse array of supports, so that a person who may not want to take advantage of one program will still have plenty of other options from which to choose (e.g., opportunities to engage in community education activities, to link socially with others, to plan and develop policy initiatives, and to connect with other community resources). In many communities, citizens who require community mental health supports struggle from a lack of individualized supports which are separate from the traditional mental health system.

ILCs now have a wealth of experience in running consumer-directed approaches and organizations. Despite this expertise, the IIC study showed that ILC staff and boards make many of the same mistakes made by other organizations. For example, they have experienced management problems around hiring practices and communication problems between staff and consumers. But, inherent in the Il philosophy is the right to make mistakes and try again. There are several areas where IICs now have expertise. Policies and practices around hiring people with disabilities, proportions of boards of directors that must be people with disabilities, managing offices, volunteer management, budgeting, grant writing. fundraising, and making people with disabilities feel welcome are some areas of practice which reflect the ILC's expertise. In mental health, there has been some literature on consumer-directed individualized support; but, more often than not, it is discussed within a case-management approach (Saleebey, 1992). Recently, the limitations of this "managerial" approach to providing support have been recognized (Nelson et al., in press).

\section{Policy}

Shifts in the thinking about support point to the need for a disability policy which focuses on rights, empowerment, community support, the elimination of barriers, and the reallocation of and access to valued resources (Bickenbach, 1993). We have a few examples in mental health where policies have moved in these directions, such as the Consumer/Survivor Development Initiative in Ontario which has resulted in over 50 consumer/survivor self-help organizations (Trainor, Shepherd, Boydell, Leff, \& Crawford, 1997). The ILCs offer further evidence of one kind of mechanism that reflects progressive policy. But such policy and funding are very limited. Policies directed at funding organizations and mediating structures that help facilitate self-help, empowerment, and citizenship are needed (Lavoie \& Stewart, 1995; Romeder, 1990).

The issue of providing support on a cross-disability basis has been identified by this study and needs to be considered in terms of policy. While our research does not imply that all supports need to be cross-disability, it raises the question: what are the circumstances in which cross-disability approaches would make the 
most sense? The strength of cross-disability lies in the creation of mediating structures which bridge or connect people with community life and peer support. Certainly the ILC experience has demonstrated its potential usefulness around the II. themes.

Traditionally, mental health policy has been the responsibility of provincial Ministries or Departments of Health. Empirical evidence (Hutchison et al., 1996) supports the suggestion that mental health policy must be much brosder than one ministry - encompassing areas such as citizenship, housing, and education. Policy changes in the area of mental health are complicated by the fact that, to date, ILCs are funded and supported largely by the federal government and mental health is supported by provincial governments.

\section{FUTURE DIRECTIONS}

This concluding section highlights some of the possibilities that exist in terms of a clearer cross-disability focus, allowing for strengthening connections between the ILCs and the mental health field. Collaborative efforts are needed in several areas:

Building knowledge. Emerging paradigms emphasize de-professionalized approaches to disability and supports. Consumer/survivor knowledge is now seen as a valuable and significant adjunct to professional knowledge and support (Trainor, et al. 1993). Thus, mental health professionals should increase their knowledge of the IL movement and ILC's practices, which would further strengthen this broader perspective of what constitutes the emerging paradigm in mental health. At the same time, ILCs should increase their knowledge of mental health, particularly related to consumer/survivor empowerment and recovery.

Building alliances. From our experience, we have noted a tendency for alternative consumer-driven paradigms to be more accepted in theory than in practice. This suggests that both the II and mental health reform movements might benefit from collaboration (Racino \& Heumann, 1992). Accordingly, we believe that II.Cs should become more of an ally for people who are working on mental health issues and who are trying to articulate an emerging paradigm and implement innovative approaches. Further, mental health reformers should learn from the II focus on consumer-directed approaches which are more explicit in the IL paradigm. Would it be desirable, therefore, for mental health reformers to collaborate with ILCs around a partnership focused on learning consumer-directed approaches?

Building community. The communities of interest that exist around the ILCs demonstrate the individual and collective benefit of community connection and participation, which allow for a stronger presence and voice for many of the individuals associated with the II movement. Nevertheless, as our study has shown, the ILCs have room to improve in terms of being more inclusive. Therefore, ILCs need to conduct research to determine whether the public bias against people with mental health problems is reproduced in their particular cross-disability setting (that is, are people with certain disabilities more highly valued in the II. movement than others?). Collaboration between mental-health and independent- 
living movements would contribute to community building, particularly in light of their common goals related to accessing full rights and citizenship.

In conclusion, closer affiliation between ILCs and the mental health field would offer consumers/survivors another "promising practice" which may be especially relevant to the empowerment process.

\section{RÉSUMÉ}

Selon les résultats d'une étude pancanadienne, les centres-ressources pour la vie autonome (CRVA) pourraient représenter une force d'innovation des plus puissantes pour le mouvement des consommateurs/survivants et consommatrices/survivantes. Les CRVA sont des centres sans but lucratif qui offrent des services aux personnes atteintes de diverses invalidités. Ayant leur racines dans la communauté, et dirigés par les consommateurs et les consommatrices, ils font la promotion de l'empowerment de l'individu et du changement communautaire. Les paradigmes sur lesquels reposent la vie autonome et la réforme en matière de santé mentale interviennent dans l'élaboration de la théorie de l'em-powerment et reconnaissent l'importance des organisations dirigées par les con-sommateurs et les consommatrices. En outre, ils font appel à une analyse sociopolitique de l'invalidité dont le champ d'intervention va audelà de l'individu et dans laquelle on reconnait que l'environnement fait partie de la problématique, En conséquence, le paradigme de réforme est axé sur la recherche de services innovateurs indépendants du système de santé mentale traditionnel. Pour que cela puisse devenir réalité, il faudra que les professionnelles et les professionnels de la santé mentale enrichissent leur connaissance de la philosophie de la vie autonome et des activités des CRVA. Ces derniers, de leur côté, devront améliorer leur connaissance de l'empowerment et du rétablissement des consommateurs/survivants et consommatrices/survivantes et évaluer minutieusement les obstacles à l'accès aux CRVA qui peuvent exister pour eux. La collaboration entre le mouvement de vie autonome et le système de santé mentale accroitra le probabilité que les CRVA deviennent une ressource plus solide pour les consommateurs/survivants et les consommatrices/ survivantes.

\section{REFERENCES}

Bickenbach, W, (1993). Physical disability and social policy. Toronto: University of Toronto Press.

Budde, J., Feighny, K., White, G., Altus, D., \& Snyder, J. (1993). Consumer control training package, Kansas, MO: University of Kansas Research \& Training Center on Independent Living.

Canadian Association of Independent Living Centres. (1991), Guidelines for Independent Living Centres in Canada. Ottawa: Author.

Carling, P. (1995). Retum to community: Building support systems for people with psyctiatric disabilities. New York: The Guilford Press.

Carpenter, S, (1993). Independent Living Centre perspectives on cross-disability and consumer control. In A. Neufeldt (Ed.), Independent living: An agenda for the '90s (pp. 83 98). Ottawa: Canadian Association of Independent Living Centres.

Council of Canadians with Disabilities. (1995). A voice of our oun. Winnipeg: Author.

DeJong, G. (1993). Three trends to look for in the American Independent Living movernent in the 1990s. In A. Neufeldt (Ed.), Independent living: An agenda for the '90s (pp. 109120). Ottawa: Canadian Association of Independent Living Centres. 
DeJong, G. (1979), Independent living: From social movement to analytic paradigm. Archives of Physical Medicine and Rehabilitation, 60, 435-446.

Dunn, P. (1998). The development of govemment independent living policies and programmes for Canadians with disabilities. Waterloo, $\mathrm{ON}$ : Wilfrid Laurier University.

Enns, H. (1986). An excerpt from the historical development of attitudes toward the handicapped: A framework for change. In A. D'ubin (Ed.), Defining the parameters of independent living. Winnipeg: Coalition of Provincial Organizations for the Handicapped.

Federal Task Force On Disability Issues. (1996). Equal citizenship for Canadians with disabilities: The will to act. Ottawa: Government of Canada.

hooks, b. (1984). Feminist theory: From margin to center, Boston: South End Press.

Hutchison, P., Pedlar, A., Dunn, P., Lord, J., \& Arai, S. (in press). Canadian Independent Living Centres: Impact on the community. International Joumal of Rehabilitation.

Hutchison, P., Pedlar, A., Lord, J., Dunn, P., McGeown, M., Taylor, A., \& Vanditelli, C. (1996). Impact of Independent Living Centres in Canada on people with disabilities. Canadian Joumal of Rehabilitation, IO(2), 99-112.

Jongbloed, L., \& Crichton, A. (1990). Difficulties in shifting from individualistic to sociopolitical policy regarding disability in Canada. Disability, Handicap \& Soctety, 5(1), 25 35.

Krogh, K., \& Petric, L. (1994). Choice, flexibility and control in community research: A guidebook, Ottawa: The Canadian Association of Independent Living Centres.

Lavoie, F., \& Stewart, M. (1995). Mutual-aid and support groups: The Canadian context. Canadian Joumal of Community Mental Health, 14(2), 5-12.

Lord, J., \& Hutchison, P. (1996). Living with a disability in Canada: Toward autonomy and integration. In The National Forum on Health (Ed.), Canada health action: Building on the legacy (pp. 376-431), Ottawa: Les Éditions MultiMondes.

Lord, J., McGeown, M., Taylor, A., \& Young, S. (1992). More than just another human service. Ottawa: Canadian Association of Independent Living Centres.

Nelson, G., Lord, J., \& Ochocka, J. (in press). Shifting the paradigm in community mental health: Toward empowerment and community. Toronto: University of Toronto Press.

Nosek, M., Fuhrer, M., \& Howland, C. (1992). Independence among people with disabilities: II. Personal Independence Profile. Rehabilitation Counselling Bulletin, 36, 2136.

Oliver, M. (1996). Understanding disability: From theory to practice, London: MacMillan.

Pardo, P. (1996). Working for change from within: The independent living movement in Canada reflects on multiculturalism. Unpublished doctoral dissertation, University of Calgary, Calgary, AB.

Racino, J., \& Heumann, J. (1992), Independent living and community life: Building coalitions among elders, people with disabilities, and our allies. Generations, 43-47. Reprint.

Rappapont, J., Reischl, T., \& Zimmerman, M. (1992). Mutual help mechanisms in the empowerment of former mental patients. In D. Saleebey (Ed.), The strengths perspective in social work practice (pp, 64-79). New York: Longman.

Romeder, J. M. (1990). The self help way. Ottawa: Canadian Council on Social Development.

Salechey, D. (1992). The strengths perspective in social work practice. New York: Longman.

Schwartz, D.B. (1992). Crossing the river: Creating a conceptual revolution in community and disability. Pennsylvania: Bookline Books.

Trainor, J., Pomeroy, E., \& Pape, B. (1993). A new framework for support. Toronto: Canadian Mental Health Association.

Trainor, J., Shepherd, M., Boydell, K., Leff, A., \& Crawford, E. (1997), Beyond the service paradigm: The impact and implications of consumer/survivor initiatives. Psy. chiatric Rehabilitation Joumal, 21, 132-140.

Valentine, F. (1994), The Canadian independent living movement: An historical overview. Ottawa: Canadian Association of Independent Living Centres. 
Woodill, G. (1992). Independent living and participation in research: A critical analysis. Toronto: Centre for Independent Living in Toronto.

Zarb, G. (1992). On the road to Damascus: First steps towards changing the relations of disability research production. Disability, Handicap and Society, 7(2), 125-138.

Zimmerman, M. (1995). Psychological empowerment: Issues and illustrations. American Joumal of Community Psychology, 23, 581-600. 